\title{
НАПРЯМИ ПІДВИЩЕННЯ ІНВЕСТИЦІЙНОЇ ПРИВАБЛИВОСТІ СІЛЬСЬКОГОСПОДАРСЬКИХ ПІДПРИЕМСТВ
}

\author{
Вашечко Юлія Валеріївна \\ аспірантка \\ Харківський національний аграрний університет ім. В.В. Докучаєва (м.Харків, Україна) \\ ORCID0000-0001-6582-9272 \\ yakushuna@gmail.com
}

Досліджено, що основними напрямами підвищення інвестиційної привабливості сільськогосподарських підприємств є врахування логістичних, територіальних особливостей та природно-кліматичних умов. Встановлено, що віддаленість від обласного центру, як найбільшого ринку збуту сільськогосподарської продукції, а також віддаленість від крупних центрів переробки продукції впливає на формування інвестиційної привабливості окремих видів сільськогосподарської продукції. Виявлено тісний взаємозв'язок між природно-сільськогосподарським районуванням та обсягом виробничих витрат на 1 га с.-г. угідь, як індикатора інвестиційної привабливості окремих видів сільськогосподарської продукції.

Ключові слова: виробничі витрати, інвестиції, інвестиційна привабливість, логістика, природно-сільськогосподарське районування, сільськогосподарські підприємства.

DOI: https://doi.org/10.32845/bsnau.2019.2.6.

Постановка проблеми. Оздоровлення української економіки, оновлення виробничих потужностей, ринкової та соціальної інфраструктури неможливе без вкладання капіталу та активізації інвестиційних процесів. Сьогодні українські підприємства відчувають інвестиційний голод, який $€$ суттєвою перепоною на шляху до економічного зростання. Несприятливий інвестиційний клімат країни віддзеркалюються на низькій інвестиційній привабливості окремих підприємств та галузей економіки. Але, навіть умовах сформованого інвестиційного клімату в державі, інвестиційна привабливість окремих сільськогосподарських підприємств в цілому і окремих галузей сільськогосподарського виробництва, при інших рівних умовах, може змінюватися в залежності від факторів, що впливають на інвестиційну привабливість. Це питання стає особливо актуальним у зв'язку з тим, що левова частка інвестицій в сільське господарство здійснюється за рахунок власних коштів товаровиробників. Тому, дуже важливим як з наукової, так і з практичної точок зору є дослідження напрямів підвищення інвестиційної привабливості сільськогосподарських підприємств, які можуть бути мобілізовані за рахунок їх власних зусиль в умовах сформованого інвестиційного клімату в державі. Аналіз останніх досліджень і публікацій. Проблемикзон. підвищення інвестиційної привабливості аграрної галузі ба сільськогосподарських підприємств постійно знаходяться у коппривабливості сільськогоспор зору вчених-економістів. Питанням підвищення інвестиційно логістична привабливість та привабливість виробництва різпривабливості присвячені праці таких вчених як І.І. Вініченко[1] них видів продукції в залежності від територіальних особлиС.О. Гуткевич [2], О.І. Гуторов [3], М.І. Кісіль [4], П.М. Майданевиц востей та природно-кліматичних умов.

[5] та інших. В той же час у науковій літературі залишаються не. достатньо висвітленими питання підвищення інвестиційної при-ливішим чинником інвестиційної привабливості сільськогосвабливості сільськогосподарських підприємств з урахуваннямподарських підприємств стає логістика. Логістика в АПК - це логістичних, територіальних особливостей та природно-сільськогосподарського районування.

Метою статті $€$ пошук шляхів підвищення інвестиційної привабливості сільськогосподарських підприємств з урахуванням територіальних особливостей.

Виклад основного матеріалу дослідження. На формування інвестиційної привабливості сільськогосподарських підприємств впливає ряд специсічних факторів. Сільське господарство, як особлива галузь економіки, відрізняються підвищеним рівнем ризику недоотримання

прибутку у зв'язку з впливом факторів природного, кліматичного та територіального характеру. Кожний інвестиційний проект має конкретну спрямованість і з найбільшою ефективністю може бути реалізований у тих регіонах, де для цього $€$ найкращі умови. Через це важливу роль у процесі обґрунтування стратегії інвестиційної діяльності підприємства відіграє оцінка територіальних та логістичних особливостей, природно-кліматичних умов, наявності необхідної інфрраструктури та потенційних центрів збуту та переробки продукції.

Що є більш інвестиційно привабливим - виробництво молока, цукрових буряків, соняшнику чи зернових? Постає зустрічне питання, в якому саме районі буде вироблятися дана продукція, в якій природно-кліматичній зоні, віддаленість чи наближеність підприємства до міста, де зосереджені переробні підприємства. Через великий обсяг логістичних витрат та через те, що швидкопсувну продукцію неможливо довести до переробних підприємств у свіжому стані, інвестиційна привабливість певних видів продукції стає нульовою. Тоді варто ставити запитання непросто про інвестиційну привабливість різних видів продукції, а про інвестиційну привабливість різних видів продукції для підприємств різних регіонів, районів чи природно-кліматичних

Отже, важливим чинником формування інвестиційної o. сфрера діяльності, об'єктом якої є організація та регулювання процесів матеріально-технічного забезпечення сільськогосподарського виробництва і збуту сільськогосподарської продукції. Тобто це управління матеріальними ресурсами під час їх закупівлі або виробництва, перевезення, зберігання.

Як зазначає O.I. Гуторов, враховуючи специфіку сільськогосподарського виробництва, агрологістика - це джерело формування додаткового прибутку за рахунок скорочення внутрішньогосподарських витрат на комплекс логістичних активностей [3, с. 33].

На розміщення і спеціалізацію впливає відстань і 
якість доріг до ринку збуту сільськогосподарської продукції. Чим менша відстань до ринків збуту і кращі дороги, тим менші транспортні витрати, тим буде вища, за інших однакових умов, економічна ефективність виробництва продукції. 3 огляду на сказане підприємствам стає доцільним розвивати ту галузь, продукція якої використовується як сировина для переробних підприємств, розміщених поблизу землекористування даного підприємства [6, с. 624].

Витрати українських аграріїв на логістичну і транспортну складову перевищують аналогічні витрати європейських і американських компаній. Це знижує конкурентоспроможність української сільськогосподарської продукції на світових ринках [7].

Для пошуку шляхів підвищення інвестиційної привабливості сільськогосподарських підприємств та досягнення високого рівня ефективності інвестицій нами було висловлена вихідна гіпотеза, яка полягала в тому, що інвестиційна привабливість сільськогосподарських підприємств, а отже, і інвестиційна привабливість виробництва окремих видів продукції для різних територій, формується в залежності від місця розташування та природно-кліматичних умов.

У зв'язку з цим, нами було здійснено групування районів Харківської області за двома групувальними ознаками по окремим видам товарної продукції. Першою групувальною ознакою виступила відстань від районного центру до обласного.

Важливим фрактором розміщення і спеціалізації є наявність ринків збуту сільськогосподарської продукції. Підприємствам вигідно збільшувати виробництво тих її видів, на які $є$ сталий попит і поблизу розташовані переробні заводи. I навпаки, часті проблеми зі збутом певних видів продукції призводять до збільшення витрат підприємства на логістику та до відмови від їх виробництва.

Райони наближені до міста Харкова, мають явні переваги з точки зору інвестицій в галузі тваринництва та молочного господарства, оскільки він $є$ крупним промисловим центром та споживачем сільськогосподарської продукції.

Оскільки, отримати інформацію про чисті інвестиції на виробництво окремих видів сільськогосподарської продукції дуже складно, в нашому дослідженні, ми оперували величиною виробничих витрат на окремі види товарної продукції. Разом з тим, інвестиції вкладаються в нематеріальні активи, а також в приріст оборотних активів, які в кінцевому підсумку трансформуються у виробничі витрати, то певною мірою обсяг інвестицій буде характеризувати тенденція зміни виробничих витрат. Тож, опосередковано, ми можемо вести мову про напрями інвестицій по тенденції зміни виробничих витрат на виробництво окремих видів продукції, які $€$ віддзеркаленням здійснених інвестицій. Отже, базою для наших розрахунків виступила величина виробничих витрат по окремим видам товарної продукції по сільськогосподарським підприємствам Харківської області за 2010 -2016рр.

Здійснивши кореляційно-регресійний аналіз залежності виробничих витрат на виробництво зернових на 1 га посівів від відстані районного центру до обласного ми отримали наступні значення. Найбільш швидкими темпами зростали виробничі витрати по зерновим у підприємствах першої групи (табл. 1).

Таблиця 1

Кореляційний аналіз залежності виробничих витрат на 1 га с.-г. угідь на вирощування зернових від відстані від районного центру до обласного в сільськогосподарських підприємствах Харківської області у $2010-2016 \mathrm{pp}$.

\begin{tabular}{|c|c|c|c|}
\hline $\begin{array}{c}\text { Групи районів за відстанню від районного центру до } \\
\text { обласного, км }\end{array}$ & Кількість районів у групі & Рівняння регресії & Коефіцієнт кореляції \\
\hline до 60,0 & 8 & $\mathrm{y}=1136,1 \mathrm{x}+376,02$ & 0,8987 \\
\hline $61-120$ & 10 & $\mathrm{y}=1074,1 \mathrm{x}+368,28$ & 0,8976 \\
\hline понад 121 & 9 & $\mathrm{y}=1068,3 \mathrm{x}+327,77$ & 0,8733 \\
\hline в середньому по Харківській області & 27 & $\mathrm{y}=1078,4 \mathrm{x}+399,34$ & 0,8888 \\
\hline
\end{tabular}

Джерело: розраховано автором на підставі статистичної звітності підприємств.

Рівняння регресії показує, що у підприємствах, розташованих до 60 км від обласного центру, виробничі витрати зростали на 1136,1 грн/га, у другій групі - на 1074,1 грн/га, в третій - на 1068,3 грн/га. Не велика, але все ж таки є перевага для вирощування зернових поблизу обласного центру. Знову ж таки, повертаючись до складової витрат на логістику, підприємства першої групи мають змогу заощаджувати на витратах на доставку засобів виробництва, які здебільшого постачаються з обласного центру, і тим самим, на заощадженні кошти, нарощувати виробництво.

Інвестиційно привабливими районами для вирощування цукрових буряків стали підприємства другої групи. Темпи зростання виробничих витрат, в якій склали 3897,4 грн/га. А в першій та третій групах - 1974,1 та 3242,6 грн/га відповідно.

Це, в першу чергу, пояснюється тим, що на території другої групи розташовані найбільші цукрові заводи Харківської області, які є центром заготівлі та переробки цукрових буряків. Тому, зважаючи на логістичну складову, виробники намагаються розташовувати вирощування цукрового буряку поблизу центру збуту. Найбільші цукрові заводи розташовані у Вовчанському, Коломацькому, Краснокутському та Балаклійському районах Харківської області, які належать до другої групи районів за відстанню до обласного центру.

Молоко $є$ швидкопсувною продукцією, яка потребує щоденної поставки до центру переробки. 3 цього виходить висновок, що інвестиційно привабливим $є$ будівництво молочних ферм поблизу переробних заводів. Оскільки, важливим чинником інвестиційної привабливості та ефективності інвестицій, є логістична привабливість - можливість доставки продукції до зони збуту, за інших однакових умов, з мінімальними витрати на транспортування.

Найбільш швидкими темпами зростали виробничі витрати по виробництву молока у районах третьої групи 3278,4 грн/гол. Виробничі витрати на виробництво молока першої групи мали тенденцію до зростання на 2518,9 грн/гол, а другої - на 2768,9 грн/гол. Це в значній мірі обумовлено тим, що в третю групу з відстанню від районного до обласного центру понад 121 км, входить Дворічанський район, в якому знаходиться потужне сільськогосподарське підприємство ПСП «Родіна», яке спеціалізується на молочному скотарстві. А також, Ізюмський район, де зосереджено великомасштабне 
виробництво молока в ТОВ «СК Восток». Інвестиційна привабливість виробництва молока в даних районах обумовлюється тим, що поряд знаходиться ПрАТ «Куп'янський молочноконсервний комбінат» - крупний центр збуту та переробки молока (виробнича потужність підприємства з переробки молока складає до 600 тонн молока на добу.) Дані розрахунки ще раз підтверджують те, що на формування інвестиційної привабливості виробництва окремих видів продукції впливає логістично-збутова складова.

Якщо вести мову про інвестиційну привабливість виробництва м'яса ВPX, варто відзначити, що в сільськогосподарських підприємствах районів третьої групи приріст виробничих витрат на 1 гол. був найвищим і становив 780,55 грн/гол., в той час як у першій групі він складав 442,63 грн/гол., в другій - 645,98 грн/гол. В даному випадку мова може йти про те, що у районах найбільш віддалених від обласного центру знаходяться потужні виробники м'ясної продукції, серед яких у Дворічанському районі - ПСП «Родіна», у Ізюмському районі - ТОВ «СК Восток». Зазначені підприємства $€$ основними постачальниками сировини для ТОВ «М'ясокомбінат» Куп'янський». Тому у сільськогосподарських підприємствах вказаних районів існують більш сприятливі логістичні умови для розвитку м'ясного скотарства, а інвестиції в галузь виробництва м'яса ВРХ, втілені у виробничих витратах на 1 гол., мають тенденцію до найбільш швидкого збільшення.

Кореляційно-регресійний аналіз дає змогу відслідкувати та оцінити також і тісноту зв'язку між показниками. Коефіцієнт регресії по усіх трьох групах районів вищий за 0,8, що характеризує високий рівень залежності темпу приросту виробничих витрат на 1 гол. з виробництва м'яса ВРХ від віддаленості районного центру від обласного у сільськогосподарських підприємствах Харківської області. Особливо високе значення коефіцієнта у другій групі районів - 0,9668, що свідчить про наявність тісного, суттєвого зв'язку між досліджуваними показниками та характеризує високу адекватність досліджень.

В області розвиненою є також галузь свинарства і попит на продукцію даної галузі постійно зростає. Аналіз інвестиційної привабливості виробництва м'яса свиней показав, що найбільш сприятливими $€$ господарства, розташовані у районах з відстанню до 60 км від районного до обласного центру.

у сільськогосподарських підприємствах вказаної групи темп приросту виробничих витрат становить 338,4 грн/гол., що пояснюється тим, що на території Харківського району знаходяться потужні комплекси з переробки м'яса Харківський, Безлюдівський, Ольхівський, Новожанівський, Салтівський м'ясокомбінати, а на території Чугуївського району - потужний свинокомплекс ПАТ «Агрокомбінат «Слобожанський».

Найнижчим є темп приросту м'яса свиней у господарствах другої групи - 226,17 грн/гол., яким дорого транспортувати продукцію як до міста Харкова, так і до найближчих пунктів переробки м'яса.

Досить високим $€$ приріст виробничих витрат у підприємствах третьої групи - 297,84 грн/гол. Тому вигідне місце розташування таких сільськогосподарських підприємств як ТОВ АФ "Лан" (Барвінківський район), ПСП ім. Фрунзе (Зачепилівський район), ПП "Агропрогрес" (Кегичівський район) ПОСП"Агросвіт" (Лозівський район), ПСП "АФ
"Прогрес" та ПуАТ "Племінний завод ім.20-річчя Жовтня" (Сахновщинський район) дозволяє їм знижувати логістичні витрати і суттєвим чином позитивно впливає на інвестиційну привабливість виробництва м'яса свиней

Таким чином, нами виявлено тісний, вагомий взаємозв'язок між темпами приросту виробничих витрат на 1 га як індикатора обсягу інвестицій в галузь та віддаленістю районного центру від обласного як показника логістичних витрат сільськогосподарських підприємств. Найбільш інвестиційно привабливими для виробництва зерна та соняшнику $€$ регіони, що знаходяться поблизу обласного центру, для цукрових буряків - підприємства в районах з потужними цукровими заводами. Для виробництва молока найбільш інвестиційно привабливими є сільськогосподарські підприємства регіонів, наближених до крупного центру збуту та переробки молока - ПрАТ «Куп'янський молочноконсервний комбінат», для виробництва м'яса ВРX - Дворічанського та Ізюмського районів.

Не менш важливий вплив на підвищення інвестиційної привабливості сільськогосподарських підприємств справляє природно-сільськогосподарське районування. Воно являє собою науково обґрунтовану систему поділу території, що враховує розподіл природних ресурсів, а також особливості їхнього сільськогосподарського використання. Районування - це своєрідна база територіального обліку природних умов і ресурсів, кількості, якісного стану й виробничої спроможності земель у системі таксономічних одиниць. Воно $€$ природно-історичною основою для розміщення сільськогосподарського виробництва, оцінки земель, розробки схем використання земельних ресурсів, схем і проектів землеустрою, систем ведення сільського господарства й землеробства та iн. [8, c 15].

Територіальна спеціалізація сільського господарства - це орієнтація певного регіону на випуск тих чи інших видів переважно товарної продукції рослинництва, тваринництва та інших галузей. Сільськогосподарське виробництво має певні особливості розміщення і територіальної спеціалізації. Ця галузь тісно пов'язана з географрічною специфікою ґрунтово-кліматичних ресурсів, що, як відомо, мають в Україні зональні особливості [9].

Не виключенням є і Харківська область. Сільськогосподарські угіддя по території Харківської області розміщені нерівномірно, їх частка в структурі земель збільшується в південних районах області у порівнянні з іншими, що пояснюється особливостями розташування регіону в межах двох природно-кліматичних зон - лісостепової та степової. Як виняток, можна зазначити Вовчанський район, який за рахунок значної площі території та орних земель має досить високий показник частки сільськогосподарських угідь.

Інвестиційна привабливість території - це характеристика її переваг і недоліків стосовно генерування та залучення інвестицій, які залежать від дії сукупності політичних, економічних та соціальних чинників. На формування інвестиційної привабливості регіонів впливають «жорсткі» фрактори, тобто ті, дію яких достатньо складно змінити за короткий проміжок часу. Серед них найважливішими є економікогеографічне положення території, природно-ресурсний потенціал, трудові ресурси, ємність внутрішнього ринку, стан інфрраструктури тощо. Ступінь впливу даних фракторів на прийняття рішень щодо інвестиційної діяльності на певній території залежить від напрямів та сфер діяльності інвесторів. 
Кожний окремий регіон володіє ресурсами, які впливають на інвестиційну привабливість. Ресурси - це об'єкти, що мають потенційну можливість їх участі у виробництві і споживанні. Кожна територія має власні ресурсні відмінності.

Проведемо дослідження за напрямом пошуку шляхів підвищення інвестиційної привабливості виробництва окремих видів сільськогосподарської продукції в залежності від природно-сільськогосподарського районування.

Кореляційно-регресійний аналіз залежності тенденції зміни виробничих витрат на 1 га на вирощування зернових від природно-сільськогосподарського районування показав, що найбільш інвестиційно привабливою зоною для вирощування зернових $є$ степова східна, в якій темп приросту виробничих витрат сягає 1085,3 грн/га. Вирощування зернових в лісостеповій та степовій південній зоні також характеризується достатньо високим нарощуванням виробничих витрат 1087,4 грн/га та 1074,2 грн/га відповідно, і можна вважати, що вони також $є$ інвестиційно привабливими регіонами для вирощування зернових.

Дослідження показали, що виробництво зерна кукурудзи в області $є$ найбільш сприятливим у сільськогосподарських підприємствах лісостепового природно-сільськогосподарського району, де темп приросту виробничих витрат на 1 га с.-г. угідь був найвищим - 1542,4 грн/га. 3 вагомим відривом наступними за інвестиційною привабливістю йдуть підприємства, розташовані в степовому південному природно-сільськогосподарському районі, де темп приросту виробничих витрат на 1 га становив 1265,5 грн/га. Темп приросту виробничих витрат на 1 га у степовому східному природно-сільськогосподарському районі був найнижчим і становив 1238,1 грн/га.

Інвестиційна привабливість виробництва насіння соняшнику з точки зору природно-сільськогосподарського районування була найвищою в степовому південному природносільськогосподарському районі. Темп приросту виробничих витрат на 1 га с.-г. угідь у підприємствах степового південного природно-сільськогосподарського регіону становив 1526,7 грн/га, у лісостеповому - 1431,5 грн/га, у степовому східному - 1307,9 грн/га.

У результаті дослідження виявлено, що найвищий темп приросту виробничих витрат на 1 га с.-г. угідь на вирощування цукрових буряків за досліджуваний період спостерігався в підприємствах степового східного природносільськогосподарському району - 4173,5 грн/га, де найбільш сприятливі умови для вирощування цукрових буряків.

У лісостеповому природно-сільськогосподарському районі темп приросту виробничих витрат на 1 га становив 3487,8 грн/га, у степовому південному - 3275,8 грн/га.

Кореляційно-регресійний аналіз залежності тенденції зміни виробничих витрат на 1 гол. при виробництві молока від природно-сільськогосподарського районування показав, що у сільськогосподарських підприємствах степового східного району темп приросту є найвищим - 3664,2 грн/гол., в той час як у лісостеповому районі - 2697,7 грн/гол., у степовому південному - 2444,6 грн/гол.

Це пов'язано з тим, що саме у степовому східному районі Харківської області зосереджена значна кількість сільськогосподарських угідь, зайнятих під сіножатями та пасовищами. А також ще й тим, що до степового східного регіону входять Балаклійський та Куп'янський райони, де знаходяться потужні центри з переробки молока - ТОВ «Балмолоко» та ПрАТ «Куп'янський молочноконсервний комбінат».

Коефріцієнт регресії вищий за 0,8 вказує на наявність вагомого, тісного зв'язку між природно-сільськогосподарським районуванням та обсягом виробничих витрат на 1 гол. та може служити критерієм надійності результатів проведених досліджень та висновків.

Беззаперечним лідером інвестиційної привабливості у виробництві м'яса ВPX є господарства степового східного природно-сільськогосподарського району Харківської області. Темпи зростання виробничих витрат, в якому знаходяться на рівні 740,58 грн/гол. Тоді як в лісостеповій зоні зростають лише на 558,09 грн/гол.

Це, в першу чергу, пов'язано з наявністю достатньої кількості пасовищ в східному степу Харківської області. А, отже, даний природно-сільськогосподарський район $\epsilon$ найбільш інвестиційно привабливим для розведення великої рогатої худоби.

В сільськогосподарських підприємствах степового південного району виробничі витрати зростають на 679,2 грн/гол., що в свою чергу вказує також на досить високу інвестиційну привабливість виробництва м'яса ВPX в даному регіоні.

Галузь свинарства в області є досить розвиненою та перспективною, тому важливе місце в процесі дослідження займає аналіз інвестиційної привабливості виробництва м'яса свиней.

Найбільш привабливими для вкладання інвестицій у виробництво м'яса свиней в області $€$ сільськогосподарські підприємства лісостепового природно-сільськогосподарського району, де темп приросту виробничих витрат становив 323,53 грн/гол.

Саме в цьому регіоні зосереджені потужні виробники продукції тваринництва Харківської області, зокрема ПуАТ "Агрокомбінат "Слобожанський" Чугуївського району (обсяг реалізації продукції в живій масі у 2016 р. становив 150862 ц), ПП "АФ Світанок" та ПП "Агро-Новоселівка 2009" Нововодолазького району. В степовому південному темп приросту був нижчим і становив 293,08 грн/гол., у степовому східному - 291,43 грн/гол.

Вивчення та аналіз логістичних, територіальних особливостей та природно-кліматичних умов дозволить сільськогосподарським виробникам здійснювати обгрунтовані інвестиційні рішення з приводу формування галузевої структури, за для мінімізації виробничих та логістичних витрат, та в кінцевому підсумку максимізації прибутку, як основного джерела інвестицій.

Висновки та перспективи подальших досліджень. Дослідження показали, що в умовах несприятливого інвестиційного клімату в державі окремі сільськогосподарські підприємства можуть впливати на свою інвестиційну привабливість та підвищувати її шляхом врахування територіальних, логістичних та природно-кліматичних особливостей. Крім того, нами було досліджено, як один з напрямів підвищення інвестиційної привабливості сільськогосподарських підприємств, рівень ризикованості виробництва та інвестування в окремі види сільськогосподарської продукції.

Логістична складова займає чільне місце серед факторів формування інвестиційного клімату сільського господарства області. Таке ж важливе місце належить природно- 
кліматичним умовам районів Харківської області, адже в результаті дослідження виявлено тісний взаємозв'язок між природно-сільськогосподарським районуванням та обсягом виробничих витрат на 1 га с.-г. угідь або на 1 гол. худоби як індикатора інвестиційної привабливості окремих видів сільськогосподарської продукції.

Урахування територіальних особливостей, природнокліматичних умов, наявності центрів збуту і переробки продукції та функціонування логістичних систем відкривають можливості для диверсифікації інвестиційних ресурсів та, в свою чергу, підвищення ефективності інвестиційної діяльності. Поряд з більш обґрунтованою територіальною диверсифікацією інвестиційної діяльності, врахування цих особливостей дасть можливість сільськогосподарським підприємствам розробляти галузеву структуру більш прийнятну для їхнього регіону, пов'язувати виробництво продукції з потенційними центрами збуту та особливостями регіональних споживчих ринків, враховувати можливий період реалізації інвестиційних проектів у окремих регіонах, виходячи з рівня розвитку їхньої інвестиційної інфрраструктури.

\section{Список літератури:}

1.Вініченко І.І. Інвестиційна діяльність аграрних підприємств : монографія. Донецьк : Юго-Восток, 2010. 444 с.

2.Гуткевич С.А Инвестиционная привлекательность аграрного сектора экономики : монография. К.: Изд-во Европ. унта, 2003. $251 \mathrm{c}$.

3.Гуторов О. І., Прозорова Н.В. Формування ефективного механізму функціонування логістичних систем сільськогосподарських підприємств. Економіка АПК. 2013. № 8. С. 33-39.

4.Кісіль М. І. Наукові дослідження інвестиційних проблем в аграрному секторі економіки. Економіка АПК. 2016. № 6. С. 84-96. URL : http://nbuv.gov.ua/UJRN/E_apk_2016_6_11.

5.Майданевич П. М. Інвестиційна привабливість підприємств аграрного сектору: теорія, методологія, практика : монограффія. Сімферополь : АРІАЛ, 2011. 386 с.

6.Андрійчук В. Г. Економіка аграрних підприємств : підручник. 2-ге вид., доп. і перероблене. К.: КНЕУ, 2002. 624 с.

7.Як погана логістика заважає українським аграріям вийти на міжнародні ринки URL http://persona.pumb.ua/ua/club/digest/detail.php

8.Мартин А.Г., Осипчук С.О., Чумаченко О.М. Природно-сільськогосподарське районування України: монографія . К. : ЦП "Компринт". 328 с.

9.Кулєшова Г.О., Озерська Т.В. Суспільно-географічні особливості фрормування інвестиційної привабливості Харківського регіону : Вісник Харківського національного університету імені В.Н. Каразіна : Геологія - Географрія - Екологія . Випуск № 1084 . Харків: ХНУ ім. В.Н. Каразіна, 2013. С. 142-146.

Vashechko Yu.V., postgraduate student, Kharkiv National Agrarian University (Kharkiv, Ukraine)

Directions of increasing the investment attractiveness of agricultural enterprises

It is considered in the article that in the conditions of the unfavourable investment climate in the country some agricultural enterprises can increase their investment attractiveness. It has been investigated that the main directions of increasing the investment attractiveness of agricultural enterprises are taking into account logistic, territorial features and natural - agricultural zoning.

Taking into account the territorial features, natural and climatic conditions, availability of sales and processing centres and the functioning of logistics systems open opportunities for diversification of investment resources and, in turn, an increase of investment attractiveness, efficiency of investments made and minimization of risks.

What is more investment attractive: milk production, sugar beet, sunflower or cereal production? The question arises as in which area the products will be produced, in which natural-climatic zone, remoteness or proximity of the enterprise to the city where processing enterprises are concentrated.Due to the large volume of logistics costs and the fact that perishable products cannot be brought to the processing plants in a fresh state, the investment attractiveness of certain types of products becomes zero. Then the question should be set, not about the investment attractiveness of different products, but the investment attractiveness of different products for the enterprises of different regions, regions or climatic zones.

Quality agro-logistics is a source for generating additional resources for investment. It is established that the distance from the regional centre, as the largest market for agricultural products, as well as the distance from large processing centres, influences the formation of investment attractiveness of certain types of agricultural products. A close correlation was found between agricultural zoning and production costs per 1 ha of farmland as an indicator of the investment attractiveness of certain types of agricultural products.

Keywords: production costs, investments, investment attractiveness, logistics, natural-agricultural zoning, agricultural enterprises.

Дата надходження до редакції: 27.01.2019 р. 